\title{
Measuring The Stock Of Human Capital In New Zealand
}

\author{
Le Thi Van Trinh ${ }^{\mathrm{a}, \mathrm{b}}$, John Gibson ${ }^{\mathrm{a}}$, Les Oxley \\ ${ }^{a}$ Department of Economics, University of Waikato \\ ${ }^{b}$ Department of Economics, University of Canterbury
}

\begin{abstract}
Human capital is increasingly believed to play an important role in the growth process; however, adequately measuring its stock still remains controversial, despite the fact that many measures of human capital have been developed. Many rely on some measure of educational experience see for example, Barro and Lee (1993, 1994, 1996 and 2001). In this study, we adopt the lifetime labour income approach outlined by Jorgenson and Fraumeni $(1989,1992)$ to measure the monetary value of the stock of human capital for New Zealand. Jorgenson and Fraumeni's method is innovative in that it simplifies the estimation process, as well as taking into account the potential value of current schooling in addition to that of past schooling. Based on data from the New Zealand Census of Population, we find that the human capital stock of the country's employed work force grew by half between 1981 and 2001, mostly due to the rise in employment level.
\end{abstract}

Keywords: Human capital, monetary value, forward-looking.

\section{Introduction}

Human capital is frequently discussed but poorly measured. Modern theories of economic growth, such as those of Romer (1986) and Jones and Manuelli (1990), emphasise human capital in their explanation of the growth process. While there is an empirical counterpart to this growth literature, the proxy measures of human capital used by authors such as Barro and Lee (1993, 1994, and 1996) have attracted considerable criticism (Temple, 2000).

Yet despite this importance, there are few existing estimates of the monetary value of human capital. Moreover, even in countries where attempts are made to estimate the value of human capital, it is not yet standard practice for official statistical agencies to include human capital in their capital stock measures (Wei, 2001). This is a surprising omission because estimates of the value of human capital predate the formal development of National Accounts statistics. For example, Petty (1690), estimated the total human capital of England to be $£ 520$ million or $£ 80$ per capita, and Dublin and Lotka (1930) also made important early contributions.

Because of these deficiencies in the educational stocks approach, Jorgenson and Fraumeni (1989, 1992a, 1992b) have returned to the earlier approach to valuing human capital, introduced by Petty (1690) and Dublin and Lotka (1930). The basic idea, as will be shown in detail below, is to value the human capital embodied in individuals as the total income that could be generated in the labour market over their lifetime. These expected labour earnings contribute to an extended notion of capital, which Jorgensen and Fraumeni (1989) include in a proposed new system of national accounts for the US economy. Outside the U.S., this method has been applied to the estimate the human capital stock for Sweden (Ahlroth et al, 1997) and Australia (Wei, 2001), both of which studies found the stock of human capital to greatly exceed that of physical capital.

In this paper we modify the formula outlined by Jorgenson and Fraumeni $(1989,1992)$ and Wei (2001) to place a value on the stock of human capital of the employed work force, or the effective human capital stock, for New Zealand. We focus only on those individuals in employment, since these people are directly participating in economic production and so their human capital is arguably a better measure of the country's productive capacity. Our estimates are based on the discounted present value of expected lifetime labour market incomes. Thus, our study is an example of a forward looking (or prospective) method of measuring human capital (Dagum and Slottje, 2000). Such methods contrast with backward looking (retrospective) methods based on cost of production concepts, and with the widely used educational stock approach.

In the empirical part of the paper we work mainly with Census of Population data from 1981-2001 to calculate the future stream of incomes that a worker of a given age, gender and education level can expect to earn. This expected income is based on cross-sectional age-income profiles, which are then combined with the probability of enrolment in further education (allowing the worker to "jump" from one profile to another), the probability of participating in the labour force and of continued employment, and age-specific mortality rates. After incorporating expected growth rates and a discount factor, it is possible to calculate the present value of lifetime income, for a person of a given gender and education level. When these per capita estimates are combined with information on the population size of 
each cohort, the aggregate value of human capital can be calculated.

\section{Previous New Zealand Literature}

Most published research on human capital in New Zealand has dealt with either changing prices -- the returns to particular educational qualifications (Maani, 1999) - or changing quantities, such as the compositional shift implied by the rising importance of the "information workforce" (Engelbrecht, 2000). There are also many studies that use proxy indicators within the educational stocks approach, such as Treasury (2001).

\section{Models}

A basic proposition in labour economics is that people choose the level of education that maximises the present value of their lifetime earnings (Borjas, 2000). Hence, a person should keep investing in human capital until the cost of the last unit (e.g., a year of schooling or qualification gained) equals the expected change in lifetime income. It is this equilibrium condition that allows lifetime income essentially a yield on human capital - to be used in place of cost of production measures when valuing the stock of human capital.

If the possibility of future enrolment to gain a higher level of education is initially ignored, it is relatively easy to get an estimate of the present value of lifetime labour income from a cross-section (Jorgenson and Fraumeni, 1992). The general principle used is that a person aged $t$ years with a certain level of education bases their expected earnings $n$ years in the future on the current earnings of people of the same education and gender who are $t+n$ years old. Early applications of this theory included Houthakker (1959), Weisbrod (1961), Miller (1965), and Graham and Webb (1979). Jorgenson and Fraumeni (1989) simplified the calculations by pointing out the fact that the present value of lifetime labour income for a person of given age is just their current annual labour income plus the present value of their expected lifetime income in the next period (where this expectation depends on employment and survival probabilities). Thus, by backwards recursion it is possible to calculate the present value of lifetime income at each age. For example, Jorgenson and Fraumeni assume that all individuals retire when they are 75 years old, so for a 74-year-old person, the present value of lifetime labour income is just their current labour income. The lifetime labour income of a 73-year-old individual is equal to the present value of lifetime labour income of the 74-year-old plus their current labour income. And so forth.

A more formal statement of this approach is:
$H K_{a}^{\ell_{i}}(x)=W_{a}^{e_{i}} Y_{a}^{e_{i}}+H K_{a+1}^{e_{i}}(x) S_{a, a+1}(1+g) /(1+i)$

where $H K(x)=$ human capital per capita, defined as the present value of lifetime labour income per capita, $Y=$ current annual labour income per capita of those employed, $W=$ employment rate, $S_{a, a+1}=$ probability of surviving one more year from age $a$, $g=$ income growth rate, $i=$ discount rate, $e_{i}=$ educational attainment of level $I, a=$ age

To implement equation (1), we make the following assumptions: The retirement age is 66 years, at which point lifetime labour incomes are set to zero. The equation holds separately for men and women. $g=2 \%$ and $i=6 \%$ (base case). These rates apply to all cohorts unless otherwise specified. Based on these assumptions, it would be possible to estimate the per capita lifetime labour income for people with any particular level of education.

While equation (1) is likely to hold for most of the population over most of their working life, there are also people enrolled in further study who in the context of the model are, essentially, trying to jump onto a higher age-earnings profile. An important innovation of the Jorgenson and Fraumeni method is that they incorporate the extra human capital of these individuals. In contrast, previous methods assumed that people undertaking further study would remain in their current cohort of educational attainment, so their further study did not count for anything. When the model allows further study, individuals face two possible earnings streams; one with continuous work and one with the possibility of delaying work for further study. Hence, lifetime labour incomes for any given cohort are a linear combination of these two earnings streams, where the weights on each depend on the probability of enrolment. Formally:

$$
\begin{aligned}
& H K_{a}^{e_{i}}(x)=W_{a}^{e_{i}} Y_{a}^{e_{i}}+\left\{\left(1-\sum_{j \in E} \sum_{t \in T} E_{a}^{j t}\right) H K_{a+1}^{e_{i}}(x)+\right. \\
& \left.+\sum_{j \in E} \sum_{t \in T} E_{a}^{j t} H K_{a+t}^{e_{i}}(x)\right\} S_{a, a+t}\{(1+g) /(1+i)\}^{t}
\end{aligned}
$$

But since the focus of our study is on the labour force, equation (2) should be modified as:

$$
\begin{aligned}
& H K_{a}^{f_{i}}(x)=W_{a}^{e_{i}} Y_{a}^{e_{i}}+H K_{a+1}^{\rho_{i}}(x) S_{a, a+1}(1+g) /(1+i) \\
& +\sum_{j \in E} \sum_{t \in T} E_{a}^{j t} L_{a+t}^{e_{i}} W_{a+t}^{e_{i}} H K_{a+t}^{\rho_{i}}(x) S_{a, a+t}\{(1+g) /(1+i)\}^{t}
\end{aligned}
$$

where $E_{a}^{j t}=$ percentage of those individuals (of the working age population) undertaking $j^{\text {th }}$ type of study in its $t^{\text {th }}$ period. $E=$ all the levels of educational attainment except the lowest, and $\quad T=$ all the study periods of E. $L=$ labour force participation rate.

Similar to Wei (2001), we assume that the potential working life is from age 21 to 65 . A work- 
study phase occurs from 21-34, where equation (3) holds. A work-only phase occurs from age 35, where equation (1) applies. While equations (1) and (3) can be estimated for any variety of education levels, we initially followed Wei and specified five groups defined by their highest qualification: higher degree; Bachelors degree; diploma; skilled labour; and unqualified. However, it is apparent that in New Zealand there is not much difference between the annual labour incomes of people in the diploma group and those in the skilled labour group. We therefore aggregated these two groups, leaving us with the following breakdown: $h=$ higher degree; $b=$ Bachelors degree; $s=$ skilled labour (UE $/ 6^{\text {th }}$ Form Certificate, Bursary $/ 7^{\text {th }}$ Form Certificate and any post-school qualifications recognised by the Census); $u=$ unqualified (School Certificate, not classifiable, other, no qualifications).

The assumptions used to implement equation (3) for the work-study stage are: The study period for a higher degree is two years, conditional on holding a Bachelors degree; The study period for a Bachelors degree is three years, regardless of previous qualification; The study period for a skilled labour qualification is two years; Individuals can only study for a higher educational attainment than they already have (Bachelors degree holders studying for a second Bachelors degree count as studying for a higher degree in the model); The number of students enrolled in anything that requires more than one period is evenly distributed among different study stages. For example, half of the higher degree students are assumed to be in their first year, the other half in their last year of study; Direct costs of study are offset by part-time earnings, so that there is no need to apply negative values of current earnings while studying.

For higher degree holders the calculation of expected lifetime labour income is simplified by the fact that they have reached the highest educational level allowed by the model. Hence, they are in the work-only stage, regardless of their age. Their lifetime labour income is:

$$
H K_{a}^{h}(x)=W_{a}^{h} Y_{a}^{h}+H K_{a+1}^{h}(x) S_{a, a+1}(1+g) /(1+i)
$$

For the cohorts whose highest current qualification is a Bachelors degree, lifetime labour income is given by:

$$
\begin{aligned}
& H K_{a}^{b}(x)=W_{a}^{b} Y_{a}^{b}+H K_{a+1}^{b} S_{a, a+1}(1+g) /(1+i)+ \\
& \frac{1}{2} E_{a}^{b-h} L_{a+1}^{h} W_{a+1}^{h} H K_{a+1}^{h}(x) S_{a, a+1}(1+g) /(1+i) \\
& +\frac{1}{2} E_{a}^{b-h} L_{a+2}^{h} W_{a+2}^{h} H K_{a+2}^{h}(x) S_{a, a+2}\{(1+g) /(1+i)\}^{2}
\end{aligned}
$$

where $E_{a}^{b-h}$ is the enrolment rate for people $a$ year old, with Bachelors degrees studying for a higher degree. Fo the cohorts whose highest current qualification falls within the "skilled" group, lifetime labour income is given by:

$$
\begin{aligned}
& H K_{a}^{s}(x)=W_{a}^{s} Y_{a}^{s}+H K_{a+1}^{s} S_{a, a+1}(1+g) /(1+i) \\
& +\frac{1}{3} E_{a}^{s-b} L_{a+1}^{b} W_{a+1}^{b} H K_{a+1}^{b}(x) S_{a, a+1}(1+g) /(1+i) \\
& +\frac{1}{3} E_{a}^{s-b} L_{a+2}^{b} W_{a+2}^{b} H K{ }_{a+2}^{b}(x) S_{a, a+2}\{(1+g) /(1+i)\}^{2} \\
& +\frac{1}{3} E_{a}^{s-b} L_{a+3}^{b} W_{a+3}^{b} H K{ }_{a+3}^{b}(x) S_{a, a+3}\{(1+g) /(1+i)\}^{3}
\end{aligned}
$$

(6)

where $E_{a}^{s-b}$ is the proportion of "skilled" individuals enrolling in a Bachelors degree. The lifetime labour income for the unqualified group is the most complex to calculate because they have the possibility of enrolling either in study towards a skilled labour qualification or in study towards a Bachelors degree:

$$
\begin{aligned}
& H K_{a}^{u}(x)=W_{a}^{u} Y_{a}^{u}+H K_{a+1}^{u}(x) S_{a, a+1}(1+g) /(1+i) \\
& +\left\{\frac{1}{2} E_{a}^{u-s} L_{a+1}^{s} W_{a+1}^{s} H K_{a+1}^{s}(x)+\frac{1}{3} E_{a}^{u-b} W_{a+1}^{b} H K_{a+1}^{b}(x)\right\} S_{a, a+1}(7) \\
& (1+g) /(1+i)+\left\{\frac{1}{2} E_{a}^{u-s} L_{a+2}^{s} W_{a+2}^{s} H K_{a+2}^{s}(x)+\right. \\
& \left.\frac{1}{3} E_{a}^{u-b} L_{a+2}^{b} W_{a+2}^{b} H K_{a+2}^{b}(x)\right\} S_{a, a+2}\{(1+g) /(1+i)\}^{2} \\
& +\frac{1}{3} E_{a}^{u-b} L_{a+3}^{b} W_{a+3}^{b} H K_{a+3}^{b}(x) S_{a, a+3}\{(1+g) /(1+i)\}^{3}
\end{aligned}
$$

where $E_{a}^{u-s}$ is the enrolment rate for those studying for a skilled labour qualification and $E_{a}^{u-b}$ is the rate for those going directly to degree study.

\section{Data description}

Data were obtained from each Census of Population from 1981 to 2001 . The data were in the form of population counts within homogeneous cells defined by age, gender, educational level (as described above), employment status, and income bracket. Depending on the particular Census, the number of cells approached 100,000 (over 800,000 cells for Census 1981), but for most of the analysis we formed the data into 360 cohorts defined by 45 ages (21-65), gender, and four educational levels. For each of these cohorts we calculated the mean annual gross income of the employed, the employment rate, and the enrolment rate.

Table 1 contains average income estimates for employees, each weighted by the number of people in the age, gender and education cohort. Many caveats are needed when interpreting these estimates. First, because New Zealand Censuses do not collect data on earnings, we have to use (gross) income as a proxy for market labour earnings. Income in New Zealand Censuses (except for NZ Census 1981) counts all sources and in this way is more broadly defined than 
in Australian Censuses, where income excludes superannuation.

Table 1: Real Annual Incomes for Employees

\begin{tabular}{lccccc}
\hline & $\mathbf{1 9 8 1}$ & $\mathbf{1 9 8 6}$ & $\mathbf{1 9 9 1}$ & $\mathbf{1 9 9 6}$ & $\mathbf{2 0 0 1}$ \\
\cline { 2 - 6 } Males & & & & & \\
Unqual & 34,171 & 32,206 & 32,165 & 33,993 & 33,997 \\
Skilled & 41,066 & 39,853 & 41,039 & 43,429 & 45,599 \\
Bach & 50,225 & 52,046 & 56,871 & 60,075 & 62,479 \\
Higher & 59,093 & 57,896 & 63,368 & 67,713 & 68,966 \\
Weight & & & & & \\
average & $\mathbf{3 7 , 5 1 5}$ & $\mathbf{3 7 , 2 7 0}$ & $\mathbf{3 8 , 6 8 8}$ & $\mathbf{4 0 , 9 7 7}$ & $\mathbf{4 1 , 9 2 3}$ \\
Females & & & & & \\
Unqual & 22,337 & 18,544 & 20,045 & 21,875 & 22,687 \\
Skilled & 28,045 & 24,291 & 26,337 & 27,891 & 29,864 \\
Bach & 35,576 & 31,645 & 36,236 & 37,243 & 40,220 \\
Higher & 41,118 & 35,451 & 40,885 & 43,625 & 47,276 \\
Weight & & & & & \\
average & $\mathbf{2 4 , 1 2 0}$ & $\mathbf{2 1 , 0 0 9}$ & $\mathbf{2 3 , 4 8 9}$ & $\mathbf{2 5 , 4 9 0}$ & $\mathbf{2 7 , 3 9 9}$ \\
Overall & & & & & \\
average & $\mathbf{3 0 , 7 3 6}$ & $\mathbf{2 9 , 1 2 5}$ & $\mathbf{3 1 , 0 2 7}$ & $\mathbf{3 3 , 1 0 7}$ & $\mathbf{3 4 , 4 4 3}$ \\
\hline
\end{tabular}

Source: New Zealand Census of Population, 1981, 1986, 1991, 1996, 2001.

Adjusted to 2001 dollars using the Prevailing Weekly Wage Index PWIQ.S4329 and All Salary \& Wage Rates LCIQ.SA53Z9.

Hopefully by using only the incomes of employees, for whom earnings are likely to predominate, we eliminate obvious biases. ${ }^{1}$ The annual income for paid employees is applied to employers and self-employed persons with the same gender-education-age-income profile. Because the data are in (varying) intervals, we use the mid-point of the closed intervals. For the open-ended interval at the top of the income distribution (e.g. $>\$ 100,000$ ) the mean income for the interval was set at 30 percent above the lower bound, while for the lowest income interval it was set at 80 percent of the upper bound (recommended by Chen, Datt and Ravallion, 1991). Those who earn nil or negative income are assumed to have a zero income and we distributed those who did not specify their income evenly across the income ranges.

The estimates in Table 1 show how income increases with the level of education, although at younger ages, degree-qualified people earn less than others. On average, real income fell slightly from 1981 to 1991 but the trend has reversed since. This trend, however, is not universal across all groups. Over the 20 year period, the unqualified have seen their income stabilise in real value, whereas the rest of the work force have experienced rising income. There is a large income gap between university degree holders and the less educated, and this gap appears to have widened over time. Although labour

\footnotetext{
${ }^{1}$ Moreover, many other studies in New Zealand use the Census data to estimate "wages" (e.g., Papps, 2001).
}

force participation among women has significantly risen the gender gap in income remains virtually unchanged after the two decades. On average, women earn 30 percent less than men. As it stands, the lower hourly earnings for females does not necessarily imply gender discrimination in wage rates; it might just mean that women tend to work in less rewarding jobs.

\section{Table 2: Enrolment Rates (Percent) by Gender and Highest Qualification}

\begin{tabular}{lccccc}
\hline & $\mathbf{1 9 8 1}$ & $\mathbf{1 9 8 6}$ & $\mathbf{1 9 9 1}$ & $\mathbf{1 9 9 6}$ & $\mathbf{2 0 0 1}$ \\
\cline { 2 - 6 } Males & & & & & \\
Unqual & 0.15 & 0.53 & 2.29 & 2.90 & 1.72 \\
Skilled & 1.19 & 1.33 & 3.62 & 12.70 & 4.24 \\
Bach & 6.96 & 7.25 & 8.90 & 11.47 & 5.27 \\
Higher & 5.50 & 6.22 & 7.66 & 12.28 & 5.22 \\
Females & & & & & \\
Unqual & 0.14 & 0.39 & 2.00 & 3.11 & 1.73 \\
Skilled & 1.01 & 1.39 & 3.64 & 15.10 & 3.46 \\
Bach & 7.29 & 8.08 & 10.62 & 12.94 & 4.30 \\
Higher & 6.57 & 5.90 & 7.97 & 12.71 & 3.99 \\
\hline
\end{tabular}

Source: New Zealand Census of Population, 1981, 1986, 1991, 1996, 2001.

Since the most recent three Censuses did not ask about student status, we had to turn to another type of question for enrolment rates. In particular, enrolment is defined as attending study or training courses in the last week (Census 1991, Q20), or attending/studying for a course at school or anywhere else in the last seven days (Census 1996, Q30), or attending/studying for more or less than twenty hours per week at school or any other places in the last four weeks (Census 2001, Q41). We only consider fulltime study and training, to be consistent with the 1981 and 1986 Censuses. Also, those who were attending full time study or training courses over the last week (or, in Census 2001, four weeks) are more likely to be students than part-timers. The 1981 Census is the only one to give enrolment information by current level of study, so we apply the enrolment pattern from the 1981 Census to the enrolment rates (by existing qualification) for the other Censuses. For example, if 80 percent of students from within the "skilled" group were attending university in 1981, we assume that 80 percent of enrolees from the "skilled" group in other Census years are undertaking study for a degree, while letting the overall enrolment rate fluctuate from Census to Census.

Enrolment rates for the population aged 21-34, classified by gender and current highest education level are reported in Table 2. Those who already hold a university degree are much more likely to be enrolled. Enrolment rates are higher for women than for men, which partly explains why the gender gap in education has significantly narrowed over time. Overall, enrolment rates in 1991 and 1996 are considerably higher than in 1981 and 1986 . 
Enrolment rates in 2001 appear low, since "enrolment" in this Census counts studying/training activities for more than 20 hours a week only, whereas "full-time" in the two preceding Censuses can include courses that last as short as one day. Nevertheless, the inconsistency in how enrolment is defined across Censuses clearly casts doubt on our enrolment data.

The last variable needed to calculate the expected value of lifetime income is survival rates, which were obtained from New Zealand Life Tables. Since survival rates are classified by gender and age only, we assume that the probabilities of surviving do not vary with the level of education.

\section{Estimation results}

\subsection{Basic results}

The average per capita lifetime labour incomes (in 2001 dollars) are reported in Table 3. These figures are weighted averages of lifetime income profiles where the weights are the number of people at each year of age. Consistent with the time trend for annual incomes, as revealed in Table 1, average lifetime incomes declined in real terms during 1981-91 and started to increase since.

The difference is, however, that although average annual income in 2001 is 9 percent higher than in 1981, average lifetime grew by less than two percent over the period. The major cause of this fall is the decrease in employment rates over the years. In particular, compared with 1981, both employment and real annual income in 1986 were lower, which explained the lower average lifetime income.

\section{Table 3: Average Lifetime Labour Income} Per Capita (\$2001)

\begin{tabular}{lccccc}
\hline & $\mathbf{1 9 8 1}$ & $\mathbf{1 9 8 6}$ & $\mathbf{1 9 9 1}$ & $\mathbf{1 9 9 6}$ & $\mathbf{2 0 0 1}$ \\
\cline { 2 - 6 } Males & & & & & \\
Unqual & 386,172 & 347,787 & 224,537 & 263,666 & 269,783 \\
Skilled & 619,774 & 543,539 & 389,138 & 506,288 & 551,219 \\
Bach & 902,717 & 905,764 & 755,465 & 733,630 & 761,405 \\
Higher & 995,213 & 920,287 & 839,763 & 784,576 & 809,069 \\
Weight & & & & & \\
average & $\mathbf{4 9 3 , 1 2 7}$ & $\mathbf{4 7 6 , 8 5 4}$ & $\mathbf{3 5 0 , 9 8 3}$ & $\mathbf{4 1 4 , 5 3 8}$ & $\mathbf{4 3 0 , 9 7 9}$ \\
$\begin{array}{l}\text { Females } \\
\text { Unqual }\end{array}$ & 263,656 & 147,296 & 150,755 & 168,837 & 172,756 \\
$\begin{array}{l}\text { Skilled } \\
\text { Bach }\end{array}$ & 385,462 & 242,187 & 246,239 & 308,413 & 341,417 \\
$\begin{array}{l}\text { Higher } \\
\text { Weight }\end{array}$ & 559,051 & 351,571 & 422,084 & 429,971 & 481,990 \\
average & $\mathbf{2 9 9 , 7 3 2}$ & $\mathbf{1 8 7 , 7 6 0}$ & $\mathbf{2 0 4 , 7 2 2}$ & $\mathbf{2 4 2 , 5 4 7}$ & $\mathbf{2 6 9 , 0 7 0}$ \\
$\begin{array}{l}\text { Overall } \\
\text { average }\end{array}$ & $\mathbf{3 9 5 , 2 5 6}$ & $\mathbf{3 3 2 , 0 5 7}$ & $\mathbf{2 7 7 , 2 6 4}$ & $\mathbf{3 2 7 , 1 4 3}$ & $\mathbf{3 4 7 , 5 9 1}$ \\
\hline
\end{tabular}

Source: Authors calculation from New Zealand Census of Population, 1981, 1986, 1991, 1996, 2001.

Adjusted to 2001 dollars using the Prevailing Weekly Wage Index PWIQ.S4329 and All Salary \& Wage Rates LCIQ.SA53Z9.
Table 4: Aggregate Value of Human Capital in New Zealand (\$2001 billion)

\begin{tabular}{lccccc}
\hline & $\mathbf{1 9 8 1}$ & $\mathbf{1 9 8 6}$ & $\mathbf{1 9 9 1}$ & $\mathbf{1 9 9 6}$ & $\mathbf{2 0 0 1}$ \\
\cline { 2 - 6 } Male & & & & & \\
Unqual & 165.4 & 135.7 & 85.5 & 118.7 & 136.6 \\
Skilled & 131.5 & 178.1 & 146.1 & 182.1 & 176.4 \\
Bach & 24.9 & 34.5 & 36.1 & 48.3 & 61.5 \\
Higher & 15.1 & 25.3 & 24.9 & 29.5 & 35.2 \\
Subtotal & $\mathbf{3 3 6 . 9}$ & $\mathbf{3 7 3 . 6}$ & $\mathbf{2 9 2 . 6}$ & $\mathbf{3 7 8 . 6}$ & $\mathbf{4 0 9 . 7}$ \\
Female & & & & & \\
Unqual & 135.1 & 74.5 & 72.3 & 89.4 & 96.3 \\
Skilled & 64.6 & 58.9 & 77.6 & 103.1 & 113.2 \\
Bach & 7.3 & 7.9 & 14.2 & 22.9 & 39.9 \\
Higher & 2.8 & 6.3 & 9.4 & 13.5 & 22.2 \\
Subtotal & $\mathbf{2 0 9 . 8}$ & $\mathbf{1 4 7 . 6}$ & $\mathbf{1 7 3 . 5}$ & $\mathbf{2 2 8 . 8}$ & $\mathbf{2 7 1 . 6}$ \\
Total & $\mathbf{5 4 6 . 7}$ & $\mathbf{5 2 1 . 2}$ & $\mathbf{4 6 6 . 1}$ & $\mathbf{6 0 7 . 4}$ & $\mathbf{6 8 1 . 4}$ \\
\hline
\end{tabular}

Source: Authors calculation from New Zealand Census of Population, 1981, 1986, 1991, 1996, 2001.

Adjusted to 2001 dollars using the Prevailing Weekly Wage Index PWIQ.S4329 and All Salary \& Wage Rates LCIQ.SA53Z9.

Annual income rose slightly in the next intercensual period, but employment declined dramatically, especially for the less educated, who make up the majority of the population. As a result, expected annual income and lifetime income increased only marginally. In the last 10 years since 1991, both employment and real annual income have risen over time, improving average lifetime income consequently.

The contribution to the stock of aggregate New Zealand human capital by each education and gender group can be found in Table 4. The share of "unqualified" people in the stock of human capital has declined from one-half of the male total in 1981 to just one-third in 2001, while the proportionate decline is even greater for women. By contrast, the human capital contributed by university degree holders has grown, in both relative and absolute terms. Indeed, this is to be expected, from what was observed earlier that annual incomes of these people have improved relatively the most and that their shares of the population have also grown. For example, in 1991, when the total human capital stock increased by a mere three percent from 1986, the capital accounted for by the university educated grew by 27 percent.

While total human capital increased by half, university degree holders' capital almost quadrupled over the last twenty years. This growth is due primarily to the larger size of the labour force, since expected annual labour income in 2001 is marginally higher than in 1981 . 


\section{Conclusions}

The paper presents some new results on the monetary value of human capital in New Zealand using a forward-looking, lifetime labour income approach. The results are preliminary and reflect some of the modelling assumptions that the imperfect New Zealand data necessitate. However, given the current activity of other researchers in the area of measuring and valuing human capital stocks, we are optimistic that some consensus about the value of the human capital stock may soon emerge.

7. Acknowledgements: Financial support of the Marsden Fund under grant UOC108 aided completion of this paper. We are particularly grateful for the assistance of Tas Papadopoulos with the provision of data.

\section{References}

Ahlroth, S., Bjorklund, A. and Forslund, A. (1997). The output of the Swedish education sector. Review of Income \& Wealth, 43 (1), 89-104.

Barro, R. J. and Lee, J-W. (1993). International comparisons of educational attainment. Journal of Monetary Economics, 32 (3), 363-394.

Barro, R.J. and Lee, J-W. (1994). Sources of economic growth. Carnegie-Rochester Conference Series on Public Policy, 40, 146.

Barro, R. J. and Lee, J-W. (1996). International measures of schooling years and schooling quality. American Economic Review, 86 (2), 218-223.

Barro, R. J and Lee, J-W. (2001). International data on educational attainment: updates and implications. Oxford Economic Papers, 53 (3), 541-563.

Borjas, G. (2000). Labor Economics. Boston, MA: McGraw-Hill.

Chen, S., Datt, G. and Ravallion, M. (1991). POVCAL: A program for calculating poverty measures from grouped data. Washington D.C.: World Bank.

Cook, L. (2000). Looking past the $20^{\text {th }}$ Century: A selection of long-term statistical trends that influence and shape public policy in New Zealand. Statistics New Zealand.

Dagum, C. and Slottje, D. J. (2000). A new method to estimate the level and distribution of household human capital with application. Structural Change and Economic Dynamics, $11(-2), 67-94$.

Dublin, L. I. and Lotka, A. (1930). The Money Value of Man. New York, NY: Ronald.

Engelbrecht, H-J. (2000). Towards a knowledge economy? Changes in New Zealand's information work force 1976-1996. Prometheus, 18 (3), 265-282.

Graham, J. W. and Webb, R. H. (1979). Stocks and depreciation of human capital: New evidence from a present-value perspective. Review of Income and Wealth, 25 (2), 209224.

Houthakker, H. S. (1959). Education and income. Review of Economics and Statistics, 41 (1), 24-28.

Jones, L., and Manuelli, R. (1990). A convex model of equilibrium growth: Theory and policy implications. Journal of Political Economy, 98 (5), 1008-1038.

Jorgenson, D. W. and Fraumeni, B. M. (1989). The accumulation of human and non-human capital, 1948-1984. In R. E. Lipsey and H. S. Tice (Eds.), The Measurement of Savings, Investment and Wealth (pp. 227-282). Chicago, IL: The University of Chicago Press.

Jorgenson, D. W. and Fraumeni, B. M. (1992). The Output of the Education Sector. In $\mathrm{Z}$. Griliches (Ed.), Output Measurement in the Services Sector (pp. 303-338). Chicago, IL: The University of Chicago Press.

Maani, S. (1999). Private and public returns to investment in secondary and higher education in New Zealand over time, 19811996. Treasury Working Paper 02/99.

Miller, H. P. (1965). Lifetime income and economic growth. American Economic Review, 55 (4), 835-844.

Papps, K. (2001). Investigating a wage curve for New Zealand. New Zealand Economic Papers, 35 (2), 218-239.

Petty, W. (1690). Political Arithmetik, reprinted in C. H. Hull (1899), The Economic Writings of Sir William Petty. Cambridge: Cambridge University Press.

Romer, P. (1986). Increasing returns and long run growth. Journal of Political Economy, 94 (5), 1002-1037.

Temple, J. (2000). Growth effects of education and social capital in the OECD countries. OECD Working Paper no. 263.

The Treasury (2001). Human capital and the inclusive economy. Treasury Working Paper 01/16.

Wei, H. (2001). Measuring the stock of human capital for Australia: A lifetime labour income approach. Paper presented at the $30^{\text {th }}$ Annual Conference of Economists, Perth, September 2001.

Weisbrod, B. A. (1961). The valuation of human capital. Journal of Political Economy, 69 (5), 425-436. 